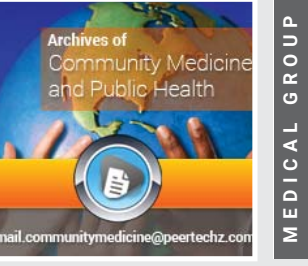

\title{
Coronavirus disease (covid-19) and public health issues in developing countries-focus on biomedical waste management
}

\author{
Kuljeet Singh Anand ${ }^{1 *}$, Bhuwan Sharma1, Rakesh Kumar \\ Mahajan ${ }^{1}$, Sanjeet Panesar ${ }^{2}$ and Prachi Dubey ${ }^{3}$ \\ 1Departments of Neurology, Biomedical Waste Division, Atal Bihari Vajpayee Institute of Medical \\ Sciences (Formerly PGIMER) \&Dr Ram Manohar Lohia Hospital, Guru Gobind Singh Indraprastha \\ University, New Delhi-110001, India \\ ${ }^{2}$ Medicine, Atal Bihari Vajpayee Institute of Medical Sciences (Formerly PGIMER) \&Dr Ram Manohar \\ Lohia Hospital, Guru Gobind Singh Indraprastha University, New Delhi-110001, India \\ ${ }^{3}$ Department of Medicine, Pandit Jawahar Lal Nehru Memorial Medical College, Raipur, India
}

Received: 21 September, 2020

Accepted: 31 October, 2020

Published: 02 November, 2020

*Corresponding author: Kuljeet Singh Anand Professor, Neurology, Atal Bihari Vajpayee Institute of Medical Sciences (Formerly PGIMER) \& Dr Rml Hospital, Guru Gobind Singh Indraprastha University, New Delhi -110001, India, Tel: 9810495019 ; E-mail:kuljeet_anand@rediffmail.com

Keywords: Covid-19; Biomedical waste; Public health https://www.peertechz.com

Check for updates

\begin{abstract}
India as a $2^{\text {nd }}$ largest populous country with a high population density with lack of awareness, burden of neglected tropical diseases and a rising prevalence of non communicable diseases, have overburdened health infrastructure. In such conditions Covid-19 pandemic is stretching the health system to its limit. Most of population is a daily wager; unawareness is there already for many basic habits. There is poor access to safe food availability, safe water and sanitation, poor food storage facility or access to processed foods, affordability of processed foods and necessity supply chain are lacking. All such aspects have a public health importance. Meanwhile to protect the community from the covid infection has led to an increase in the Biomedical Waste (BMW) production for which no separate guideline is formulated as the WHO guidelines for waste management suffice to manage covid related waste too. The segregation of COVID waste as per requirements of Schedule I of the BMW Management Rules 2016 with some additional safety criteria is sufficient to handle the waste. The waste generated at hospital and quarantine camps or houses if handled according to the guidelines then the problem can be steadily tackled with minimum problems. This pandemic Covid-19 disease can be used as a tool to educate the population. "Empowering masses about modes of transmission, debunking myths, associated risks and preventive strategies" and this will be is a cost effective key instrument not only for Covid 19 but also for other infectious disease.
\end{abstract}

\section{Introduction}

Severe acute respiratory syndrome coronavirus 2 (SARSCoV-2), which causes coronavirus disease (COVID-19), was first identified in December 2019 in Wuhan city, China, and later spread to many provinces in China [1]. On January 30th, 2020, the WHO declared COVID-19 a public health emergency of international concern [2]. The first SARS-CoV-2 positive case in India was reported in the state of Kerala on January 30th, 2020. Initially cases were rising slowly and it took 110 days to reach 100,000 marks, but subsequently it grows exponentially and now 60000-70000 cases are reported daily, with more than 7 million total cases. India has reached in second position in list of countries with highest number of cases, behind only to USA [3]. In India there are only 0.53 hospital beds per 1000 population [4] and with such speed of Covid 19 cases can easily tear down the Indian health infrastructure. The Covid 19 is affecting the population not only by the disease itself but also by creating other public health issues. Even the developed nations with high Global Health Security Index (GHSI) are badly hit.The catastrophic capability of this infectious disease was grossly underestimated in the developed countries such as the USA and many countries in Europe and they paid heavy price for this imprudence in the form of a very rapid surge in disease transmission and high fatality. Developing countries are already facing the brunt of inadequate resources of health care, poor 
nutrition and financial constraints in their public spending on health. There is already overwhelming scarcity of critical care resources in health sector like intensive care management units and ventilators. There is already a high population density and lack of awareness more over the existing morbidities are higher in India in form of neglected tropical diseases, rising non communicable diseases, and as a denominator $2^{\text {nd }}$ largest populous country having overburdened health infrastructure. Thus the pandemic Covid-19 disease is acting as a double edged sword. In situation like this "Empowering masses about modes of transmission, debunking myths, associated risks and preventive strategies" is a cost effective key instrument that should be widely and judiciously used amidst scarcity of resources.

\section{Biomedical waste management in covid time}

The appalling increase in the number of people/regions/ countries infected with SARS-CoV-2 coupled with exponential increase in generation of bio medical waste from covid patients has indicated that the world may be overrun by COVID-waste and the outcome of this plenitude will have a deep impact on sustainable waste management practices in the coming years [6]. The resilience of our society and waste management practices are under scientific scrutiny with the contrasting reports of stability of SARS-CoV-2 on various surfaces [7]. The traces of this virus has been observed on plastics for 6.8 $\mathrm{h}$, stainless steel for $5.6 \mathrm{~h}$ [8], and the outer layer of surgical mask up to 7 days [9]. It clearly indicates that COVID-waste (like needles and syringes used for blood samples, surgical facemasks, and PPE) can have a longer persistence of SARS$\mathrm{CoV}-2$. Virus transmissions from the contaminated dry surfaces have also been postulated including self inoculation of mucous membranes of the eyes, nose, and mouth [10]. The exposure to COVID-waste may potentially increase the virus spread by increasing the reproductive number (Ro) from its determined range between 2.2 and $3.58[11,12]$. The major route of SARSCoV-2 transmission is splatters or splashes liberated during breathing, coughing, sneezing etc. of an infected person. The improper management of COVID-waste would expose common people and healthcare workers in danger of infection spread. Thus, effective management of COVID-waste including the appropriate disinfection and disposal techniques would be absolute necessity to control the pandemic spread.

\section{Indian guidelines for managing biomedical waste [13]}

COVID-19 isolation wards: In India, Bio Medical Waste is managed as per provisions of Bio Medical Waste Management Rules 2016. These rules prescribe that occupier of health care facility shall hand over the segregated waste to Operator of Common Bio-medical Waste Treatment Facility [CBWTF] for treatment, processing and final disposal. The rules also obligate the occupier to disinfect infectious waste on-site before handing over to the operator of CBWTF. During this outbreak of COVID-19 pandemic, when an all out effort was being attempted to contain this outbreak; Central Pollution Control Board [CPCB] of the Ministry of Environment, Forests \& Climate Change issued Guidelines in March 2020 for handling, treatment and disposal of waste generated during treatment/ diagnosis/quarantine of COVID-19 patients. Second, $3^{\text {rd }}$ and $4^{\text {th }}$ revisions of these guidelines were issued in the months of April, June and July 2020 to fill the gaps in the management of COVID waste.

The segregation of COVID waste into different categories was also as per requirements of Schedule I of the BMW Management Rules 2016 but some additional safety criteria were mandated which included;

A) Use of double bags for collection of waste from COVID areas and additional

B) labeling of bags with sticker of COVID waste.

C) Separate color coded foot operated bins for placing waste bags. Separate area for temporary storage of COVID waste. Separate trolleys to be earmarked to transport COVID waste.

D) Disinfection of waste bags and bins with $1 \%$ Sodium hypochlorite solution before handing over to the operator.

E) Dedicated sanitation workers to be stationed for handling COVID waste and workers to be provided adequate personal protective equipment so that they don't get infected while handling this category of waste.

\section{Quarantine camps/Homes or Home-care facilities for Covid 19}

Biomedical waste if any generated from quarantine centres/camps is to be collected separately in yellow coloured bags (suitable for biomedical waste collection) provided by the urban local bodies (ULBs). These bags could be handed over to the waste collectors authorized by the ULB's at door steps or deposited at designated deposition centres established by the local bodies.

General solid waste (household waste) generated from quarantine centres or camps should be handed over to the waste collector identified by the Urban Local Bodies or as per the prevailing local methods of disposing general solid waste.

\section{Role of public health in disease control}

Non-pharmaceutical interventions remain central for management of COVID-19 because there are no licensed vaccines or coronavirus antivirals. If the situation changes towards much wider community transmission with multiple international foci, the WHO strategy of containment for elimination could need to be adjusted to include mitigation strategies combined with the following activities currently recommended by STAG-IH on the WHO website [14].

First, close monitoring is needed of changes in epidemiology and of the effectiveness of public health strategies and their social acceptance.

Second, continuous monitoring and evaluation is needed of enhanced communication strategies that provide general 
populations and vulnerable population groups (to those who are most at risk) with actionable information for self-protection, including identification of symptoms, and clear guidance for treatment seeking.

Third, continued intensive source control is needed in the epicentre, isolation of patients and persons testing positive for COVID-19, contact tracing and health monitoring, strict health facility infection prevention and control, and use of other active public health control interventions with continued active surveillance and containment activities at all other sites where outbreaks are occurring.

Fourth, continued containment activities are needed around sites where there are infected people and transmission among contacts, with intensive study to provide information on transmissibility, modes of transmission, and natural history of infection, with regular reporting to WHO and sharing of data.

Fifth, intensified active surveillance is needed for possible infections in all countries using the WHO-recommended surveillance case definition.

Sixth, preparation for resilience of health systems in all countries is needed, as is done at the time of seasonal influenza, anticipating severe infections and course of disease in older people and other populations identified to be at risk of severe disease.

Seventh, if widespread community transmission is established, there should then be consideration of a transition to include mitigation activities, especially if contact tracing becomes ineffective or overwhelming and an inefficient use of resources. Examples of mitigation activities include cancelling public gatherings, school closure, tele / remote working, home isolation, observation of the health of symptomatic individuals supported by telephone or online health consultation, and provision of essential life support such as oxygen supplies, mechanical ventilators and extracorporeal membrane oxygenation (ECMO) equipment.

Eighth, serological tests need to be developed that can estimate current and previous infections in general populations.

Finally, continued research is important to understand the source of the outbreak by study of animals and animal handlers in markets to provide evidence necessary for prevention of future coronavirus outbreaks.

\section{India's action in Covid 19}

In this pandemic, India's approach was fast as well as aggressive. For this, it has already received accolades from Dr. Henk Bekedam, the WHO's representative in India [15]. Other commendable efforts so taken are announcing a \$22.6 billion economic stimulus plan, to provide relief to millions of poor people hit by the nationwide lockdown. For empowering masses, a dedicated webpage-A "novel coronavirus" with detailed information/advice on corona virus along with phone helpline numbers has been created on the Ministry of Health's website, also "Aarogyasetu" -a COVID tracker app has been launched that assesses the risk of getting infected with COVID. The promotion of inter-ministerial coordination too helped in managing the escalating rise by judicious use of resources like creation of containment cells in railway trains/schools/ colleges, roping in of alternative medicine professionals, promotion of research in vaccine/drugs against COVID, encouraging manufacturing of antimalarial drugs and even joining hands with other countries in its containment. Hence, India along with other developing countries can culminate the COVID threat with amalgam of tested strategies along with visionary approach.

\section{Conclusion}

Since SARS CoV2 can survive for long and variable periods outside of its host, the potential of these infected fomites in spread of this infectious agent can't be underplayed. Any laxity in appropriateness in handling of COVID waste at the sites of generation may lead to community spread. The existing resources would require priority strengthening to efficiently manage the challenge of COVID waste as per regulatory requirements. Public participation, timely collection in appropriate containers and fast disposal of covid waste would be key movers in effective management of this emerged category of waste. Public health is now recognized as a distinct discipline globally. However, opportunities of learning, research, and practice in this field are limited in India. The speed with which the virus is spreading, even among countries that are ranked high for their outstanding health systems, has left nations and economies stunned. This pandemic has taught developing nations, a lesson regarding the importance of adequate planning and preparation to effectively deal with a future emergency. Furthermore, such situations are best managed through effective coordination among the federal, provincial and local governments along with hub and satellite hospitals. There is a need to practice social distancing and promote public health measures with the help of the community and local government coordination. At present, social distancing has proven to be effective, but prolonging the lockdown can also increase poverty, mental illness and social inequality at individual level, and can affect the country's economy in long term which may have indirect effect of health and infrastructure as well as the population in a feedback manner. Furthermore, public health systems are under severe pressure as the COVID-19 pandemic continues and the government is unable to deal with other diseases, resulting in future long-term health concerns.

\section{References}

1. Huang C, Wang Y, Li X, Ren L, Zhao J, et al. (2020) Clinical features of patients infected with 2019 novel coronavirus in Wuhan, China. Lancet 395: 497-506. Link: https://bit.ly/2HSKTYF

2. World Health Organization (2020) Coronavirus. Link: https://bit.ly/35NVmwV

3. Ministry of health and family welfare (2020) Covid-19. India. Link: https://bit.ly/2TBUW7k

4. OECD (2020) Hospital beds (indicator). Link: https://bit.ly/2HPvRD8

5. Gibson L, Rush D (2020) Novel coronavirus in Cape Town informal settlements: 
Feasibility of using informal dwelling outlines to identify high risk areas for COVID-19 transmission from a social distancing perspective. JMIR Public Health Surveill 6: e18844. Link: https://bit.ly/2TGqSr2

6. Cutler S (2020) Mounting medical waste from COVID-19 emphasizes the need for a sustainable waste management strategy. Link: https://bit.ly/3oL7RIN

7. Kampf G, Todt D., Pfaender S, Steinmann E (2020) Persistance of coronavirus on inanimate surfaces and its inactivation with bio-cidal agents. J Hosp Infect 104: 246-251. Link: https://bit.ly/35QNjPT

8. Doremalen V, Bushmaker T, Morris DH, Holbrook MG, Gamble A, et al. (2020) Aerosol and surface stability of SARS CoV-2 as compared with SARS CoV-1. N Engl J Med 382: 1564-1567. Link: https://bit.ly/3ecPXDI

9. Chin A, Chu J, Perera M, Hui K, Yen H, et al. (2020) Stability of SARS CoV2 in different environmental conditions. Lancet Microbe 1: e10. Link: https://bit.ly/32gazGn

10. Otter JA, Donskey C, Yezli S, Douthwaite S, Goldberg SD, et al. (2016) Transmission of SARS and MERS corona virus and influenza virus in healthcare setting: the possible role of dry surface contamination. J Hosp Infect 92: 235250. Link: https://bit.ly/2Jrgn9r

11. Li Q, Guan X, Wu P, Wang X, Zhou L, et al. (2020) Early transmission dynamics in Wuhan, china of novel corona virus infected pneumonia. N Engl J Med 382: 1199-207. Link: https://bit.ly/3mGC2ZA

12. Zhao S, Lin Q, Ran J, Musa SS, Yang G, et al. (2020) Preliminary estimation of the basic reproduction number of novel corona virus (2019-nCoV-2) in China from 2019-2020: a data driven analysis in early phase of outbreak. Int J Infect Dis 92: 214-217. Link: https://bit.ly/3kNrPK0

13. Central Pollution Control Board. Guidelines for Handling, Treatment and Disposal of Waste Generated during Treatment/Diagnosis/ Quarantine of COVID-19 Patients (Fourth revision). Link: https://bit.ly/37Vmz3p

14. Heymann D, Shindo N (2020) Covid 19: what is next in public health. Lancet? 395: 542-545. Link: https://bit.ly/2JghFDS

15. Coronavirus Pandemic: WHO Representative 'Very Impressed' with India's Response. 2020. Link: https://bit.ly/3edRg52
Discover a bigger Impact and Visibility of your article publication with

Peertechz Publications

\section{Highlights}

* Signatory publisher of ORCID

* Signatory Publisher of DORA (San Francisco Declaration on Research Assessment)

* Articles archived in worlds' renowned service providers such as Portico, CNKI, AGRIS, TDNet, Base (Bielefeld University Library), CrossRef, Scilit, J-Gate etc.

* Journals indexed in ICMJE, SHERPA/ROMEO, Google Scholar etc.

* OAI-PMH (Open Archives Initiative Protocol for Metadata Harvesting)

* Dedicated Editorial Board for every journal

* Accurate and rapid peer-review process

* Increased citations of published articles through promotions

* Reduced timeline for article publication

Submit your articles and experience a new surge in publication services

(https://www.peertechz.com/submission).

Peertechz journals wishes everlasting success in your every endeavours.

Copyright: @ 2020 Anand KS, et al. This is an open-access article distributed under the terms of the Creative Commons Attribution License, which permits unrestricted use, distribution, and reproduction in any medium, provided the original author and source are credited. 